\title{
Density Functional Calculation of the Structure and Electronic Properties of $\mathrm{Cu}_{n} \mathrm{O}_{n}(\mathrm{n}=1-4)$ Clusters
}

\author{
Gyun-Tack Bae and Randall W. Hall
}

Department of Chemistry, Louisiana State University, Baton Rouge, Louisiana 70808

\begin{abstract}
We have performed ab initio Monte Carlo simulated annealing simulations and density functional theory calculations to study the structures and stabilities of copper oxide clusters, $\mathrm{Cu}_{n} \mathrm{O}_{n}(n=1-4)$. We determined the lowest energy structures of neutral, positive and negatively charged copper oxide clusters using the B3LYP/LANL2DZ model chemistry. The geometries are found to undergo a structural change from two- to three-dimensions when $n=4$ in the neutral clusters. We have investigated the size dependence of selected electronic properties of the binding energies, second differences of the energy, ionization potentials, electron affinities, and HOMO-LUMO gaps. We also have investigated fragmentation channels and charge distributions.
\end{abstract}

Keywords: Densitiy functional theory, copper oxide clusters.

\section{Introduction}

Studies of clusters help understand the evolution of properties from isolated atoms to bulk matter as well as to probe the details of solvation. Recently, it has been found that metal oxide clusters contribute to health hazards [1,2, 3, 4]. The high speed collision of clusters with solid surfaces can give rise to short-lived species at extreme temperature and pressures. It has been shown that these impact-heated clusters provide an environment in which chemical reactions can be induced. Energetic cluster impact also has the potential for technological application in the formation of particularly dense and coherent metal and semiconductor thin films. Metal oxide clusters formed during combustion react with many organic compounds. [5, 6] The practical uses of metal clusters are well known and include catalysis, nanomaterials, and composite materials.

Experimental [7,8,910 and computational 11,12,1314] studies exist for some small copper oxide clusters (1-2 copper atoms.) Three isomers have been suggested as possible structures for $\mathrm{CuO}_{2}$ [15] : bent $\mathrm{CuOO}$ (bent, $\mathrm{C}_{s}$ ), linear $\mathrm{OCuO}$, and $\mathrm{C}_{2 v} \mathrm{OCuO}$. Evidence has been found both the bent $\mathrm{CuOO}$ [16,17,18,19] and the linear $\mathrm{OCuO}$ [15, 20, 21]. Vibrational frequencies have been calculated [20] for $\mathrm{CuO}_{3}, \mathrm{OCuO}_{2}^{-}$, and $\mathrm{Cu}\left(\mathrm{O}_{3}\right)^{-}$. Recently, the structures of $\mathrm{CuO}_{4}, \mathrm{CuO}_{5}[22]$ and neutral and negatively charged $\mathrm{CuO}_{6}$ [23] were determined using plane-wave density functional theory. In addition, $\mathrm{Cu}_{2} \mathrm{O}_{x}(\mathrm{x}=1-4)$ have been studied using

G. Allen et al. (Eds.): ICCS 2009, Part II, LNCS 5545, pp. 122-130, 2009.

(C) Springer-Verlag Berlin Heidelberg 2009 
anion photoelectron spectroscopy and density functional calculations [24,25]. In this paper, we investigate the electronic and geometric structures of neutral and charged copper oxide clusters $\left((\mathrm{CuO})_{n} \mathrm{n}=1-4\right)$.

\section{Method of Calculation}

\subsection{Ab Initio Monte Carlo Simulation}

The study of atomic and molecular clusters is hindered by the existence of multiple isomers for a given size cluster. Without an a priori knowledge of the global energy minima, the use of computer simulation methods, such as simulated annealing, often allow the location of global minima. For this reason, we performed $a b$ initio simulated annealing Monte Carlo (MC) simulations (using Gaussian 03 and homegrown scripts) 26] to locate stable geometric structures for these clusters. The simulations used multiple starting geometries for each cluster size. The temperature was decreased from $2000 \mathrm{~K}$ to $300 \mathrm{~K}$ over a period of up to $500 \mathrm{MC}$ steps. We used the B3LYP (Becke's 3-parameter exchange functional with LeeYang-Parr correlation energy functional) [27,28,29] version of DFT to calculate the energy.

\subsection{Basis Sets}

We evaluated several basis sets as candidates for our studies. These were $6-31 \mathrm{G}^{* *}$ [30, 31, 32], 6-31++G $\mathrm{G}^{* *}$ [33, 30, 34, 35, 36, 37], 6-311G** 36, 38, 39, 40], 6-311++G** 35, 41, LANL2DZ 42, 43, 44, and DGDZVP 45, 46. MC simulations were followed by standard geometry optimization using 47. Calculations found the lowest energy clusters for $\mathrm{Cu}_{2} \mathrm{O}_{n}(n=1-4)$ shown in Fig. 1. For $\mathrm{Cu}_{2} \mathrm{O}_{3}$ and $\mathrm{Cu}_{2} \mathrm{O}_{4}$, different isomers were found depending on basis set $\left(\mathrm{Cu}_{2} \mathrm{O}_{3}-\mathrm{a}: 6-31 \mathrm{G}^{* *} ; \mathrm{Cu}_{2} \mathrm{O}_{3}-\mathrm{b}: 6-31++\mathrm{G}^{* *}, 6-311 \mathrm{G}^{* *}, 6-311++\mathrm{G}^{* *}\right.$, LANL2DZ and DGDZVP; $\mathrm{Cu}_{2} \mathrm{O}_{4}$-a: $6-31++\mathrm{G}^{* *}, 6-311++\mathrm{G}^{* *}$, LANL2DZ and DGDZVP; $\mathrm{Cu}_{2} \mathrm{O}_{4}-\mathrm{b}: 6-31 \mathrm{G}^{* *}$ and $6-311 \mathrm{G}^{* *}$.) Experimental data of electron affinities of $\mathrm{Cu}_{2} \mathrm{O}$ to $\mathrm{Cu}_{2} \mathrm{O}_{4}$ clusters is available [4]. A comparison of calculated and measured electron affinities are shown in Table 1 . The best agreement with experimental data is found with the LANL2DZ basis set, which is therefore used in the remainder of this work.

Table 1. Electron affinity comparing basis sets with experimental data

\begin{tabular}{cccccccc}
\hline \hline \multicolumn{7}{c}{ Electron Affinities (eV) } \\
\hline & $6-31 \mathrm{G}^{* *}$ & $6-31++\mathrm{G}^{* *}$ & $6-311 \mathrm{G}^{* *}$ & $6-311++\mathrm{G}^{* *}$ & LANL2DZ DGDZVP EXP [48] \\
$\mathrm{Cu}_{2} \mathrm{O}$ & 0.94 & 1.27 & 0.14 & 1.24 & 1.15 & 1.15 & 1.10 \\
$\mathrm{Cu}_{2} \mathrm{O}_{2}$ & 1.41 & 2.33 & 0.89 & 1.76 & 2.41 & 2.24 & 2.46 \\
$\mathrm{Cu}_{2} \mathrm{O}_{3}$ & 2.35 & 2.65 & 1.67 & 3.09 & 3.25 & 3.08 & 3.54 \\
$\mathrm{Cu}_{2} \mathrm{O}_{4}$ & 3.26 & 3.34 & 2.75 & 3.35 & 3.54 & 3.31 & 3.50 \\
\hline \hline
\end{tabular}




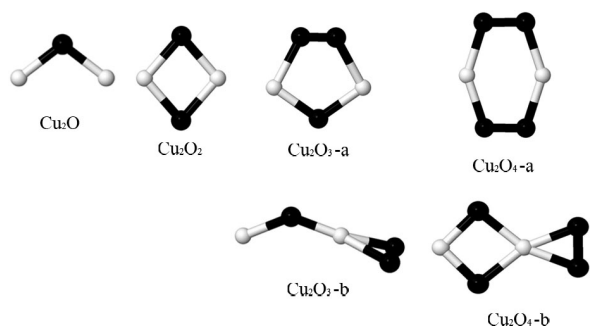

Fig. 1. Lowest energy clusters for $\mathrm{Cu}_{2} \mathrm{O}_{n}, n=1-4$. Different basis sets give different lowest energy isomers for $n=3$ and $4\left(\mathrm{Cu}_{2} \mathrm{O}_{3}-\mathrm{a}\right.$ : 6-31G**; $\mathrm{Cu}_{2} \mathrm{O}_{3}-\mathrm{b}: 6-31++\mathrm{G}^{* *}, 6-$ $311 \mathrm{G}^{* *}, 6-311++\mathrm{G}^{* *}$, LANL2DZ and DGDZVP; $\mathrm{Cu}_{2} \mathrm{O}_{4}-\mathrm{a}: 6-31++\mathrm{G}^{* *}, 6-311++\mathrm{G}^{* *}$, LANL2DZ and DGDZVP; $\mathrm{Cu}_{2} \mathrm{O}_{4}$-b: 6-31G** and 6-311G**)(see Table 1 for details.) White atoms are coppers and black atoms are oxygens.

\section{Results and Discussion}

\subsection{Geometric Structure}

The optimized structures of neutral, positive and negatively charged $(\mathrm{CuO})_{n}$ clusters with $\mathrm{n}=1-4$ are shown in Fig. 2. The low-lying spin states (i.e., singlet, doublet, triplet, and quartet) of a given cluster were considered in the calculations. Every neutral copper oxide cluster, $(\mathrm{CuO})_{n}$, can be made from $\mathrm{Cu}_{n-1} \mathrm{O}_{n-1}$ cluster by attaching a $\mathrm{Cu}-\mathrm{O}$ molecule to the side of $\mathrm{Cu}_{n-1} \mathrm{O}_{n-1}$ cluster.

In $\mathrm{CuO}$, the $\mathrm{Cu}-\mathrm{O}$ distances are $1.76 \AA$ (cation), $1.76 \AA$ (neutral) and $1.74 \AA$ (anion). Our calculated value of neutral $\mathrm{Cu}-\mathrm{O}$ distance is in good agreement experimental value of $1.73 \AA$. [49] The spin states of optimized structures

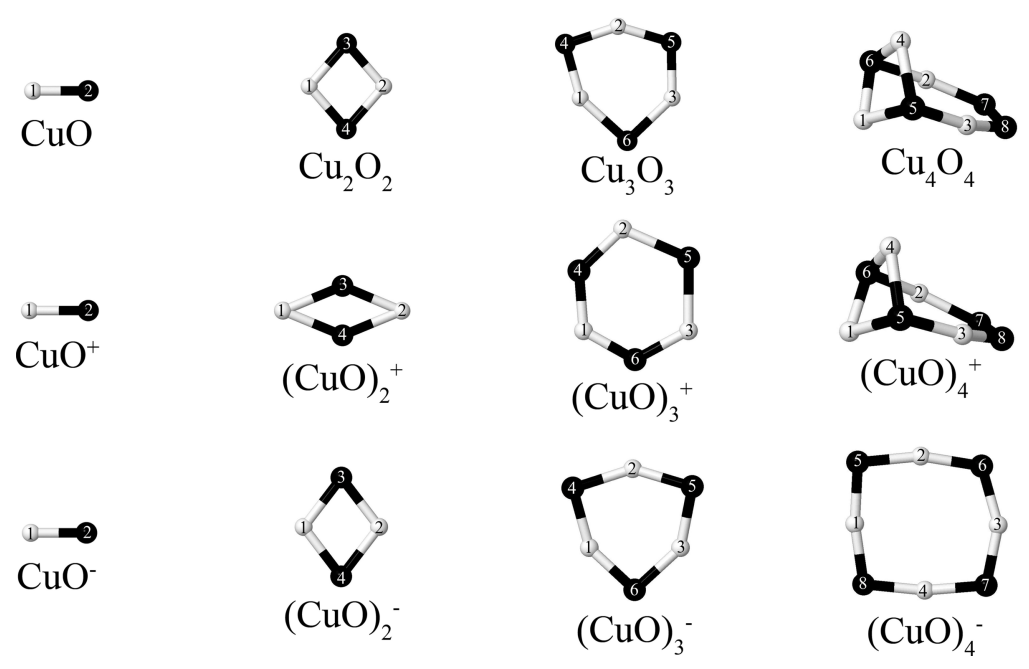

Fig. 2. Optimized structures of neutral, positively, and negatively charged $(\mathrm{CuO})_{n}$ clusters with $n=1-4$. White atoms are coppers and black atoms are oxygens. 
are doublet, singlet and singlet for the neutral, cation and anion clusters, respectively. The structure of the lowest energy $\mathrm{Cu}_{2} \mathrm{O}_{2}$ cluster is rhombus in our simulations and calculations. The spin states of optimized structures are singlet, doublet, and doublet for the neutral, cation and anion clusters, respectively. Wang et al. 24] and Dai et al. 25] have suggested minimum energy structures for $\mathrm{Cu}_{2} \mathrm{O}_{2}$. Wang, et. al., suggest the structure is a rhombus while Dai, et. al, suggest the structure is linear or near linear. The $\mathrm{Cu}-\mathrm{O}$ bond length of $\mathrm{Cu}_{2} \mathrm{O}_{2}$ structure found by Wang et al. is $1.78 \AA$ and the angle of $\mathrm{Cu}-\mathrm{O}-\mathrm{Cu}$ of $\mathrm{Cu}_{2} \mathrm{O}_{2}$ structure is $80^{\circ}$. Our Cu-O bond lengths are $2.01 \AA$ (cation), $1.86 \AA$ (neutral) and $1.92 \AA$ (anion) and average angle $\mathrm{Cu}-\mathrm{O}-\mathrm{Cu}$ of $\mathrm{Cu}_{2} \mathrm{O}_{2}$ structure is $81.2^{\circ}$. The $\mathrm{Cu}-$ $\mathrm{O}-\mathrm{Cu}$ bond angles are $135^{\circ}$ (cation), $82^{\circ}$ (neutral), and $75^{\circ}$ (anion). $\mathrm{Cu}_{3} \mathrm{O}_{3}$ clusters have nearly planar structures. The neutral cluster is a quartet while the charged clusters have triplet ground states. The average $\mathrm{Cu}-\mathrm{O}-\mathrm{Cu}$ bond angles are $121.8^{\circ}$ (cation), $98.1^{\circ}$ (neutral), and $94.2^{\circ}$ (anion). The $\mathrm{Cu}-\mathrm{O}-\mathrm{Cu}$ bond angles are smaller than the $\mathrm{O}-\mathrm{Cu}-\mathrm{O}$ bond angles while the $\mathrm{CuO}$ are shorter than found in the $\mathrm{Cu}_{2} \mathrm{O}_{2}$ clusters. Our $\mathrm{Cu}-\mathrm{O}$ bond lengths are $1.89 \AA$ (cation), $1.90 \AA$ (neutral) and $1.85 \AA$ (anion). The $\mathrm{Cu}_{4} \mathrm{O}_{4}$ cluster is the first nonplanar structure found for $\mathrm{Cu}_{n} \mathrm{O}_{n}$ and consists of 2 copper atoms above and below the plane of a $\mathrm{Cu}_{2} \mathrm{O}_{4}$ unit. A similar structure is found for the cation cluster, while the anion cluster is planar. The spin states of optimized structures are triplet (neutral) and doublet (cation and anion.) Our Cu-O bond lengths are $1.92 \AA$ (cation), $1.94 \AA$ (neutral) and $1.81 \AA$ (anion).

\subsection{Binding Energies, Ionization Potential, Electron Affinities}

The binding energies per atom have been calculated from

$$
E_{b}=\left[n E(C u)+n E(O)-E\left(C u_{n} O_{n}\right)\right] / 2 n
$$

Table 2. Bond lengths $(\AA)$ of $\mathrm{Cu}-\mathrm{O}$ in $(\mathrm{CuO})_{n}(\mathrm{n}=1-4)$ clusters

\begin{tabular}{|c|c|c|}
\hline & Clusters & $\overline{d_{1-2}}$ \\
\hline \multirow{3}{*}{$\mathrm{CuO}$} & $\mathrm{CuO}$ & $d_{1-2}=1.81$ \\
\hline & $\mathrm{CuO}^{+}$ & $d_{1-2}=1.76$ \\
\hline & $\mathrm{CuO}^{-}$ & $d_{1-2}=1.74$ \\
\hline \multirow{3}{*}{$\mathrm{Cu}_{2} \mathrm{O}_{2}$} & $\mathrm{Cu}_{2} \mathrm{O}_{2}$ & $d_{1-3}=1.86 d_{1-4}=1.86 d_{2-3}=1.86 d_{2-4}=1.86$ \\
\hline & $\mathrm{Cu}_{2} \mathrm{O}_{2}^{+}$ & $d_{1-3}=2.01 d_{1-4}=2.01 d_{2-3}=2.01 d_{2-4}=2.01$ \\
\hline & $\mathrm{Cu}_{2} \mathrm{O}_{2}^{-}$ & $d_{1-3}=1.92 d_{1-4}=1.92 d_{2-3}=1.92 d_{2-4}=1.92$ \\
\hline \multirow{3}{*}{$\mathrm{Cu}_{3} \mathrm{O}_{3}$} & $\mathrm{Cu}_{3} \mathrm{O}_{3}$ & $d_{1-4}=1.83 d_{1-6}=2.06 d_{2-4}=1.81 d_{2-5}=1.83 d_{3-5}=1.83 d_{3-6}=2.03$ \\
\hline & $\mathrm{Cu}_{3} \mathrm{O}_{3}^{+}$ & $d_{1-4}=1.75 d_{1-6}=1.77 d_{2-4}=1.78 d_{2-5}=2.13 d_{3-5}=2.12 d_{3-6}=1.79$ \\
\hline & $\mathrm{Cu}_{3} \mathrm{O}_{3}^{+}$ & $d_{1-4}=1.84 d_{1-6}=1.85 d_{2-4}=1.85 d_{2-5}=1.85 d_{3-5}=1.85 d_{3-6}=1.85$ \\
\hline \multirow{5}{*}{$\mathrm{Cu}_{4} \mathrm{O}_{4}$} & $\mathrm{Cu}_{4} \mathrm{O}_{4}$ & $\begin{array}{l}d_{1-5}=1.96 d_{1-6}=1.97 d_{2-6}=1.88 d_{2-7}=1.93 \\
d_{3-5}=1.88 d_{3-8}=1.93 d_{4-5}=1.97 d_{4-6}=1.96\end{array}$ \\
\hline & $\mathrm{Cun}^{+}$ & $d_{1-5}=1.94 d_{1-6}=1.93 d_{2-6}=1.88 d_{2-7}=1.94$ \\
\hline & $\mathrm{U}_{4} \mathrm{U}_{4}$ & $d_{3-5}=1.87 d_{3-8}=1.93 d_{4-5}=1.92 d_{4-6}=1.95$ \\
\hline & & $d_{1-5}=1.81 d_{1-8}=1.81 d_{2-5}=1.80 d_{2-6}=1.79$ \\
\hline & $\mathrm{Cu}_{4} \mathrm{O}_{4}$ & $d_{3-6}=1.81 d_{3-7}=1.83 d_{4-7}=1.80 d_{4-8}=1.80$ \\
\hline
\end{tabular}


Table 3. Spin states, ionization energies (IE), electron affinities (EA), and binding energies $\left(\mathrm{E}_{b}\right)$ for $\mathrm{Cu}_{n} \mathrm{O}_{n}, n=1-4$. Energies are in electron volts and are calculated using the B3LYP/LANL2DZ model chemistry.

\begin{tabular}{lcccc}
\hline \hline & Spin State & IE & EA & $\mathrm{E}_{b}$ \\
\hline $\mathrm{CuO}$ & doublet & & & \\
$\mathrm{CuO}^{+}$ & singlet & 12.25 & 1.35 & 1.22 \\
$\mathrm{CuO}^{-}$ & singlet & & & \\
\hline $\mathrm{Cu}_{2} \mathrm{O}_{2}$ & singlet & & & \\
$\mathrm{Cu}_{2} \mathrm{O}_{2}^{+}$ & doublet & 8.24 & 2.35 & 1.85 \\
$\mathrm{Cu}_{2} \mathrm{O}_{2}^{-}$ & doublet & & & \\
\hline $\mathrm{Cu}_{3} \mathrm{O}_{3}$ & quartet & & & \\
$\mathrm{Cu}_{3} \mathrm{O}_{3}^{+}$ & triplet & 9.36 & 3.65 & 2.19 \\
$\mathrm{Cu}_{3} \mathrm{O}_{3}^{-}$ & triplet & & & \\
\hline $\mathrm{Cu}_{4} \mathrm{O}_{4}$ & triplet & & & \\
$\mathrm{Cu}_{4} \mathrm{O}_{4}^{+}$ & doublet & 8.37 & 3.40 & 2.35 \\
$\mathrm{Cu}_{4} \mathrm{O}_{4}^{-}$ & doublet & & & \\
\hline \hline
\end{tabular}

Figure 3 shows the binding energy per atom, $\mathrm{E}_{b}$, as a function of number of copper atoms in the cluster. There is a rapid increase from a binding energy of $1.24 \mathrm{eV}(\mathrm{n}=1)$ to $2.22 \mathrm{eV}(\mathrm{n}=3$.) The $\mathrm{n}=4$ cluster has a similar binding energy to the $\mathrm{n}=3$ cluster, though not close to the bulk work function of $>5$ $\mathrm{eV}$. Thus studies of larger clusters are necessary to more closely examine the size evolution of the properties of these clusters.

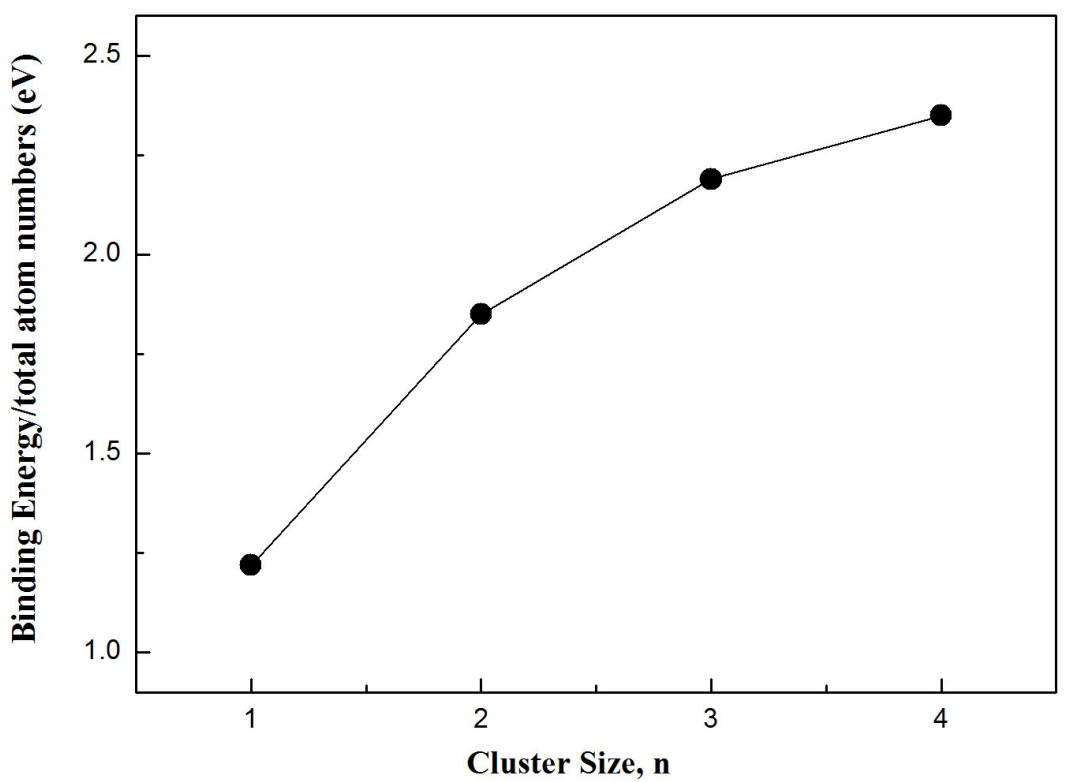

Fig. 3. Binding energies of neutral $(\mathrm{CuO})_{n}$ clusters with $\mathrm{n}=1-4$ 


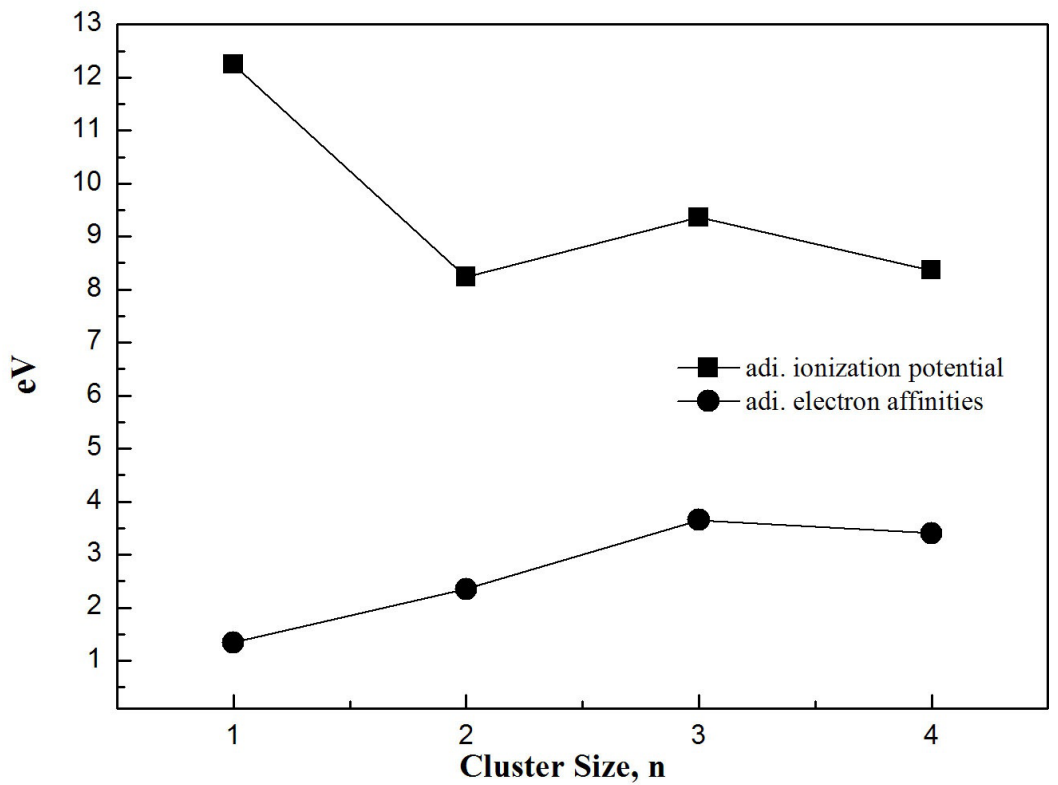

Fig. 4. Calculated adiabatic ionization potential and electron affinities of $(\mathrm{CuO})_{n}$ clusters with $n=1-4$

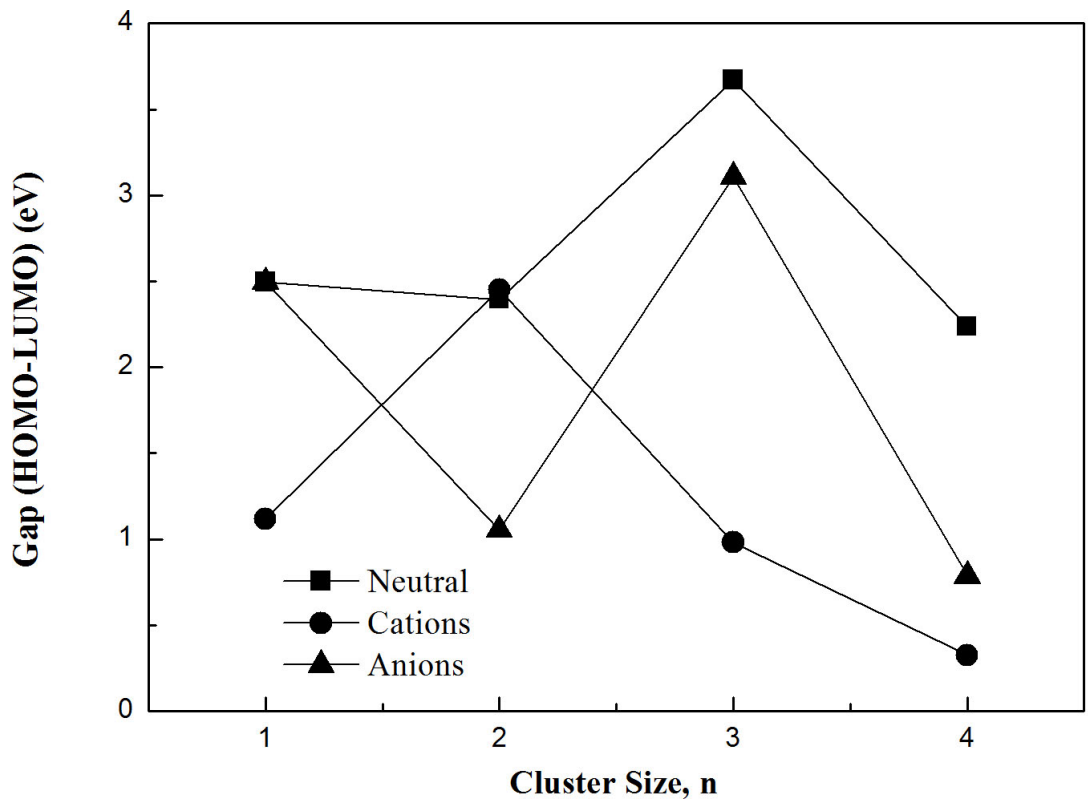

Fig. 5. Calculated HOMO-LUMO gap of $(\mathrm{CuO})_{n}$ clusters with $\mathrm{n}=1-4$ 
Table 4. Fragmentation channels of $(\mathrm{CuO})_{n}$ clusters with $\mathrm{n}=1-4$. Energies are in $\mathrm{kcal} / \mathrm{mol}$.

\begin{tabular}{|c|c|}
\hline & $\Delta E$ \\
\hline$(\mathrm{CuO})_{2} \rightarrow \mathrm{CuO}+\mathrm{CuO}$ & 57.91 \\
\hline$(\mathrm{CuO})_{3} \rightarrow \mathrm{Cu}_{2} \mathrm{O}_{2}+\mathrm{CuO}$ & 75.90 \\
\hline$(\mathrm{CuO})_{4} \rightarrow \mathrm{Cu}_{3} \mathrm{O}_{3}+\mathrm{CuO}$ & 75.56 \\
\hline$\rightarrow \mathrm{Cu}_{2} \mathrm{O}_{2}+\mathrm{Cu}_{2} \mathrm{O}_{2}$ & 93.55 \\
\hline
\end{tabular}

Fig. 4 shows the adiabatic ionization potentials $\left(\operatorname{IP}\left(\mathrm{X}_{n}\right)=\mathrm{E}\left(\mathrm{X}_{n}^{+}\right)-\mathrm{E}\left(\mathrm{X}_{n}\right)\right)$ and electron affinities $\left(\mathrm{EA}\left(\mathrm{X}_{n}\right)=\mathrm{E}\left(\mathrm{X}_{n}\right)-\mathrm{E}\left(\mathrm{X}_{n}^{-}\right)\right.$. These properties display the evenodd oscillation often seen in clusters. The HOMO-LUMO gaps in these clusters are shown in Fig. 5.

\subsection{Fragmentation Channels}

We have also calculated the fragmentation energies of $(\mathrm{CuO})_{n}(\mathrm{n}=1-4)$ clusters for various dissociation pathways. The fragmentation channels of $(\mathrm{CuO})_{n}$ clusters are shown in Table 4. The fragmentation energy of $\mathrm{Cu}_{2} \mathrm{O}_{2}$ cluster requires the least amount of energy to fragment and the lowest energy pathway for all clusters is to lose a single $\mathrm{CuO}$ group.

\section{Conclusions}

The electronic and structural properties of small copper oxide clusters have been studied using density functional theory and several basis sets. Comparison with existing experimental work demonstrated that the LANL2DZ basis set is in best agreement and therefore was used study study $\mathrm{Cu}_{n} \mathrm{O}_{n}$ clusters. It was found that the clusters are planar for up to $\mathrm{n}=3$ and then become nonplanar. Ionization energies, electron affinities, and binding energies demonstrate some oscillations with cluster size, as is typical for clusters. Larger clusters must be studied in order to explore the approach to bulk properties.

\section{Acknowledgements}

This work was supported by NSF CBET-0625548 and CTS-0404314 grants and computational facilities at Louisiana State University (www.hpc.lsu.edu) and the Louisiana Optical Network Initiative (www.loni.org).

\section{References}

1. Pope III, C.A., Burnett, R.T., Thun, M.J., Calle, E.E., Krewski, D., Ito, K., Thurston, G.D.: JAMA 287, 1132 (2002)

2. Delfino, R.J., Gong, H., Linn, W.S., Pellizzari, E.D., Hu, Y.: Environ. Health Persp. 111, 647 (2003) 
3. Donaldson, K., Li, X.Y., MacNee, W.: J. Aerosol Sci. 29, 553 (1998)

4. Air Quality Criteria for Particulate Matter 1-3, EPA/600/P-95/001 (1996)

5. Lighty, J.S., Veranth, J.M., Sarofim, A.F.: J. Air Waste Manage. Assoc. 50, 1565 (2000)

6. Linak, W.P., Wendt, J.O.L.: Fuel Process Technol. 39, 173 (1994)

7. De Heer, W.A.: Rev. Mod. Phys. 65, 611 (1993)

8. Morse, M.D.: Chem. Rev. 86, 1049 (1986)

9. Leopold, D.G., Ho, J., Lineberger, W.C.: J. Chem. Phys. 86, 1715 (1987)

10. Lee, T.H., Ervin, K.M.: J. Phys. Chem. 98, 10023 (1994)

11. Brack, M.: Rev. Mod. Phys. 65, 677 (1993)

12. Aakeby, H., Panas, I., Pettersson, L.G.M., Siegbahn, P., Wahlgren, U.: J. Phys. Chem. 94, 5471 (1990)

13. Calaminici, P., Kster, A.M., Russo, N., Salahub, D.R.: J. Chem. Phys. 107, 4066 (1996)

14. Cao, Z., Wang, Y., Zhu, J., Wu, W., Zhang, Q.: J. Phys. Chem. B 106, 9649 (2002)

15. Wu, H., Desai, S.R., Wang, L.S.: J. Chem. Phys. 103, 4363 (1995)

16. Kasai, P.H., Jones, P.M.: J. Phys. Chem. 90, 4239 (1986)

17. Mattar, S.M., Ozin, G.A.: J. Phys. Chem. 92, 3511 (1988)

18. Bauschlicher, C.W., Langhoff, S.R., Partridge, H., Sodupe, M.: J. Phys. Chem. 97, 856 (1993)

19. Hrusak, J., Koch, W., Schwarz, H.: J. Chem. Phys. 101, 3898 (1994)

20. Chertihin, G.V., Andrews, L., Bauschlicher, C.W.: J. Phys. Chem. A 101, 4026 (1997)

21. Deng, K., Yang, J., Yuan, L., Zhu, Q.: J. Chem. Phys. 111, 1477 (1999)

22. Massobrio, C., Pouillon, Y.: J. Chem. Phys. 119, 8305 (2003)

23. Pouillon, Y., Massobrio, C.: Chem. Phys. Lett. 356, 469 (2002)

24. Wang, L.S., Wu, H., Desai, S.R., Lou, L.: Phys. Rev. B 53, 8028 (1996)

25. Dai, B., Tian, L., Yang, J.: J. Chem. Phys. 120, 2746 (2004)

26. Frisch, M.J., Trucks, G.W., Schlegel, H.B., Scuseria, G.E., Robb, M.A., Cheeseman, J.R., Montgomery Jr, J.A., Vreven, T., Kudin, K.N., Burant, J.C., Millam, J.M., Iyengar, S.S., Tomasi, J., Barone, V., Mennucci, B., Cossi, M., Scalmani, G., Rega, N., Petersson, G.A., Nakatsuji, H., Hada, M., Ehara, M., Toyota, K., Fukuda, R., Hasegawa, J., Ishida, M., Nakajima, T., Honda, Y., Kitao, O., Nakai, H., Klene, M., Li, X., Knox, J.E., Hratchian, H.P., Cross, J.B., Bakken, V., Adamo, C., Jaramillo, J., Gomperts, R., Stratmann, R.E., Yazyev, O., Austin, A.J., Cammi, R., Pomelli, C., Ochterski, J.W., Ayala, P.Y., Morokuma, K., Voth, G.A., Salvador, P., Dannenberg, J.J., Zakrzewski, V.G., Dapprich, S., Daniels, A.D., Strain, M.C., Farkas, O., Malick, D.K., Rabuck, A.D., Raghavachari, K., Foresman, J.B., Ortiz, J.V., Cui, Q., Baboul, A.G., Clifford, S., Cioslowski, J., Stefanov, B.B., Liu, G., Liashenko, A., Piskorz, P., Komaromi, I., Martin, R.L., Fox, D.J., Keith, T., Al-Laham, M.A., Peng, C.Y., Nanayakkara, A., Challacombe, M., Gill, P.M.W., Johnson, B., Chen, W., Wong, M.W., Gonzalez, C., Pople, J.A.: Gaussian 03, Revision C.02. Gaussian, Inc., Wallingford CT (2004)

27. Lee, C., Yang, W., Parr, R.G.: Phys. Rev. B 37, 785 (1988)

28. Becke, A.D.: J. Chem. Phys. 98, 1372 (1993)

29. Stephens, P.J., Devlin, F.J., Chabalowski, C.F.: J. Phys. Chem. 98, 11623 (1994)

30. Francl, M.M., Petro, W.J., Hehre, W.J., Binkley, J.S., Gordon, M.S., DeFrees, D.J., Pople, J.A.: J. Chem. Phys. 77, 3654 (1982)

31. Rassolov, V.A., Pople, J.A., Ratner, M.A., Windus, T.L.: J. Chem. Phys. 109, 1223 (1998) 
32. Hariharan, P.C., Pople, J.A.: Theo. Chim. Acta. 28, 213 (1973)

33. Hehre, W.J., Ditchfield, R., Pople, J.A.: J. Chem. Phys. 56, 2257 (1972)

34. Dill, J.D., Pople, J.A.: J. Chem. Phys. 62, 2921 (1975)

35. Clark, T., Chandrasekhar, J., Schleyer, P.v.R.: J. Comp. Chem. 4, 294 (1983)

36. Krishnam, R., Binkley, J.S., Seeger, R., Pople, J.A.: J. Chem. Phys. 72, 650 (1980)

37. Gill, P.M.W., Johnson, B.G., Pople, J.A., Frisch, M.: J. Chem. Phys. Lett. 197, 499 (1992)

38. Blaudeau, J.-P., McGrath, M.P., Curtiss, L.A., Radom, L.: J. Chem. Phys. 107, 5016 (1997)

39. Curtiss, L.A., McGrath, M.P., Blaudeau, J.-P., Davis, N.E., Binning Jr, R.C., Radom, L.: J. Chem. Phys. 103, 6104 (1995)

40. Glukhovtsev, M.N., Pross, A., McGrath, M.P., Radom, L.: J. Chem. Phys. 1995, 103 (1878)

41. Krishnan, R., Binkley, J.S., Seeger, R., Pople, J.A.: J. Chem. Phys. 72, 650 (1980)

42. Hay, P.J., Wadt, W.R.: J. Chem. Phys. 82, 270 (1985)

43. Wadt, W.R., Hay, P.J.: J. Chem. Phys. 82, 284 (1985)

44. Hay, P.J., Wadt, W.R.: J. Chem. Phys. 82, 299 (1985)

45. Godbout, N., Salahub, D.R., Andzelm, J., Wimmer, E.: Can. J. Chem. 70, 560 (1992)

46. Sosa, C., Andzelm, J., Elkin, B.C., Wimmer, E., Dobbs, K.D., Dixon, D.A.: J. Phys. Chem. 96, 6630 (1992)

47. Schmidt, M.W., Baldridge, K.K., Boatz, J.A., Elbert, S.T., Gordon, M.S., Jensen, J.H., Koseki, S., Matsunaga, N., Nguyen, K.A., Su, S.J., Windus, T.L., Dupuis, M., Montgomery, J.A.: GAMESS VERSION = 24 MAR 2007 (R3). J.Comput. Chem. 14, 1347 (1993)

48. Lou, L.: Phys. Rev. B 53, 8028 (1996)

49. Polak, M.L., Gilles, M.K., Ho, J., Lineberger, W.C.: J. Phys. Chem. 95, 3460 (1991) 